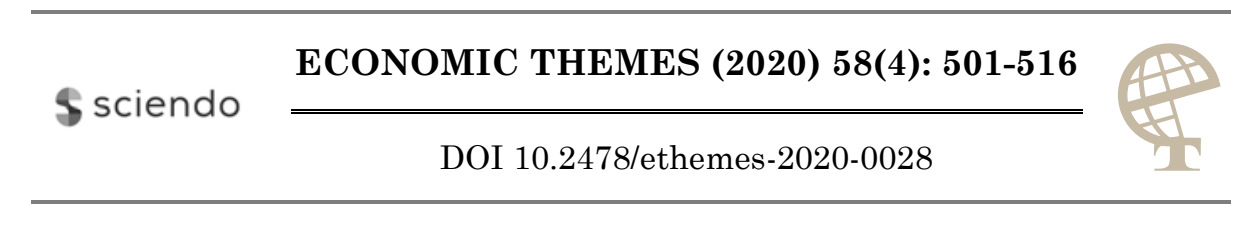

\title{
THE INFLUENCE OF FOREIGN DIRECT INVESTMENT TREATMENT IN DOMESTIC LEGISLATION ON THE ECONOMIC DEVELOPMENT OF THE REPUBLIC OF SERBIA
}

\author{
Milica Vukajlović \\ MSc student at University of Niš, Faculty of Economics, Serbia \\ $\triangle$ mvukajlovic29@gmail.com \\ Tamara Milenković Kerković \\ University of Niš, Faculty of Economics, Serbia \\ $\triangle$ tamara.kerkovic@eknfak.ni.ac.rs \\ Dragana Radenković Jocié \\ University of Niš, Faculty of Economics, Serbia \\ $\bowtie$ draganarj61@gmail.com
}

UDC

339.727.2:

$338.1(497.11)$

Review paper

Received:

06.11.2020

Accepted:

24.12.2020
Abstract: Serbia has been following a policy of subsidizing foreign direct investments since 2006 and it pays great attention to this type of investment capital in the field of development of our economy. Whether this can be considered as justified is a question to which this paper aims to provide an answer. Do the positive aspects of foreign direct investment necessarily come to the leading position in the country importing capital? The analysis of the positive effects of foreign direct investments on the economy of the host country shows that the multiple benefits of such attracted capital certainly exist, but that their manifestation is not unconditional and will depend on numerous factors. Due to the fact that the subsidy policy is current, the criteria for granting state incentives defined by the current regulation should be set so as to contribute to the manifestation of positive effects of foreign direct investments on the Serbian economy. However, their analysis shows that this is not the case. In addition, the impact that foreign direct investment has had on the Serbian economy indicates that the subsidy policy has not given the expected results. Having this in mind, the impact that the treatment of foreign direct investments in domestic legislation has on the economic development of the Republic of Serbia cannot be assessed as satisfactory.

Keywords: foreign direct investments, subsidies, Serbia, economic development, foreign investors, legislation

JEL classification: E22, F21, F43 


\section{Introduction}

The subject of this paper is the impact that the treatment of foreign direct investment in domestic legislation has on the desired economic progress and the exit of Serbia from the circle of countries lagging behind in development.

The aim of the research is to assess the justification of the importance attached to foreign direct investment in the field of development of the Serbian economy, the treatment that is in line with the attached importance in domestic legislation and the assessment of the strategy used to increase the inflow of this type of investment into the country by taking into account the results it has produced.

Within the first part of this paper, the determination of foreign direct investments is considered, and then the significance that this form of investment capital can have for the economic development of the host country.

The second part of the paper provides an overview of the current legal solutions governing the field of direct investment and a more detailed overview of the current Regulation on determining the criteria for awarding incentives to attract direct investment.

The last part contains the consideration of the attractiveness of Serbia as an investment location, the consideration of the justification of the subsidy policy, the criteria used for the allocation of subsidies and the manifested effects of foreign capital whose inflow was realized in the form of direct investments.

\section{Foreign direct investments and their impact on participants}

We can approach the definition of foreign direct investment led by the desire to obtain answers to the following questions: what do foreign direct investments represent for the economy of the country importing capital, and what for a specific foreign investor? In other words, we can approach the definition of foreign direct investments from the macro and micro aspects.

From the macro aspect, foreign direct investments represent a type of engagement of foreign savings, i.e. capital originating from abroad, which is a "supplement to the domestic investment fund". With this type of foreign investment, the economy of the country importing capital uses foreign savings to expand the capital fund at its disposal, without the obligation to return the mentioned funds increased by interest, as is the case with loans.

Viewed from the micro aspect, there are many definitions given within the academic public that point to the essence of the concept of foreign direct investment. We will use the definition of the British economist John Harry Dunning: "Foreign direct investment is a phenomenon when an investor located in one country (country of origin) acquires an asset in another country (host country) 
with the intention to manage this asset. In most cases, both the investor and the assets he manages abroad are business enterprises. In such cases, the investor is typically referred to as the parent company and the assets abroad as a branch or subsidiary company." (Veličković, 2019, p. 45)

The impact that foreign direct investment has on the economy of the country importing capital will be considered with a focus on underdeveloped and developing countries, given that Serbia belongs to this circle of countries.

The following positive effects on the economy of the country importing capital are expected from foreign direct investments:

- Increase in gross domestic product;

- Strengthening competition in the domestic market;

- Increase in employment;

- Spillover effect;

- Inflow of capital that does not affect the increase of the country's indebtedness;

- Providing access to the international market of goods and capital;

- Increase in exports;

- Increase in foreign exchange supply;

- Increase of budget revenues, etc.

The opening of completely new companies increases the volume of production in the country and, thus, increases the gross domestic product, and the inflow of foreign direct investment and it can encourage the growth of domestic investment, which in this case is considered a contribution of foreign direct investment to economic growth as explained by the author Kovacevic (Veličković, 2019, p. 60).

When it comes to intensifying competition on the domestic market, or the market of underdeveloped and developing countries, which in this case are considered as host countries, there are opposing opinions in the professional public. One group of authors talks about the possibility of forming competitive pressure on domestic companies that would increase their efforts in the field of productivity and economic efficiency, the development of new, better products, sales methods because that is the only way to survive. However, another group of authors points out that foreign investors are actually multinational companies which, due to their economic strength, which is greater than the social product of the host country, easily "swallow" the existing competition on the market of these countries and occupy a monopoly position. Another reason, due to which multinational companies do not create a competitive environment, is the fact that they often make exclusive production agreements with the state bureaucracy and this way they stifle competition because these agreements provide them with privileges inaccessible to domestic investors. Subsidies, tax exemptions, ceding of land and other benefits which developing countries provide them and which are easier to obtain than domestic investors create an unequal position in the market. It can also be noticed 
that domestic investors directly finance their competitors because the taxes they pay through subsidies are transferred to foreign investors.

Increasing employment is an effect that must logically manifest itself at first glance. However, it should be noted here that the mandatory creation of new jobs occurs only when it comes to greenfield investments, while when we talk about the privatization of state-owned enterprises in transition countries, in many cases there was a reduction in the number of employees. In other forms of taking control of existing companies, it is generally expected that the existing number of jobs will be preserved. Thus, the impact on employment will depend on whether new production facilities are opened or existing ones are bought.

In addition to this, the indirect effects on employment should not be forgotten. Foreign investors can establish cooperation with domestic companies, which may cause the need to increase the number of workers. However, the second scenario should not be excluded and it presents the possibility that the foreign investor already has its own supply chain. Then, if the foreign investor took over the domestic company that cooperation had established with domestic suppliers, this cooperation will be terminated and domestic raw materials substituted by imports. In the case that the investment is made in the form of a greenfield investment, the expectations of establishing cooperation with domestic companies will remain unfulfilled.

Furthermore, there are expectations that the growth of exports caused by the inflow of foreign direct investments will lead to an increase in the general level of economic activity, which then inevitably creates employment growth. The same sequence of events is expected after the state's engagement in the field of investment projects, which will begin as part of the efforts undertaken in order to attract foreign direct investments.

Finally, we should mention the case when multinational companies are squeezing out domestic competitors, small and medium enterprises, and thus contributing to job losses.

Spillover effect refers to the transfer of technology and knowledge from foreign investors to domestic companies, which should increase their productivity. Thus, foreign direct investments create positive external effects. We distinguish between horizontal (intra industrial) and vertical (inter industrial) spillover effects. The horizontal spillover effect is directed towards competitors, while the vertical spillover effect takes place in the direction of suppliers and customers. These transfers take place within the country importing capital, so they are suppliers, buyers and competitors from the domestic market.

An overflow or increase in productivity due to the presence of foreign firms can occur through three channels. The first channel is created by foreign companies, often demanding higher standards when it comes to semi-finished products and raw materials by which they are supplied, in comparison with those 
that domestic companies meet. Therefore, in order to form a partnership, domestic companies will be ready to improve their production process and apply new knowledge and technology. What is more, they can compete in the sale of better quality semi-finished products and raw materials. The effect would be guaranteed if foreign investors provided them with technological support and organized training. The second channel through which knowledge is transferred can take two forms. The first is reflected in the transfer of employees who have undergone training and acquired specific knowledge from a foreign company to domestic companies, and the second implies that employees from foreign companies leave to start their own companies. The third transfer channel is also formed in two ways: by domestic companies learning new management practices from foreign firms with the help of quit managers or by imitating innovations seen by foreign investors. (Brussevich \& Tan, 2018, str. 2-3)

Research within the academic community has revealed that the positive effects of spillovers are more common if domestic companies are technologically more advanced, i.e. able to absorb the necessary knowledge. Otherwise, domestic companies will have a problem with too high costs that would be created by the purchase of patents and the transfer of technological knowledge. Furthermore, the manifestation of the vertical effect will not be possible if multinational companies do not establish cooperation with domestic suppliers. The existence of this effect will also depend on whether foreign investors actually introduce advanced technology or whether they represent low-tech advanced activities, as well as how much foreign investors are connected to sectors that have the capacity to establish partnerships with them.

Foreign direct investment can affect the export performance of the economy if the increase in production is realized in exports. Another dimension of the impact of foreign direct investment relates to the connection of branches of foreign companies in the host country with their parent companies in the countries of origin, as a result of which exports may increase. The management experience of foreign companies, modern technology, as well as their better integration into international production chains should certainly be added, which can also have a positive impact on exports. (Kovačević R., 2019) When we talk about the influence of foreign investors on the balance of payments, we should also take into account the value of imports that these companies realize during the year.

There is no doubt that by paying profit taxes, foreign investors contribute to the increase of budget revenues, however, the overall effect of their presence on the budget will determine the relationship between the paid taxes and the subsidies they enjoy. Also, it should not be forgotten that foreign investors are supported by incentives in the form of tax exemptions or tax reliefs that reduce their contribution to public revenues. There is also the possibility that multinational companies reduce their tax liabilities through transfer prices. 
The analysis of potential positive effects of foreign direct investments confirmed the need for the existence of the epithet "potential". Actually, it is very important to emphasize that the multiple benefits of this type of investment capital certainly exist, but also that their manifestation is not unconditional and will depend on many factors, which the previously presented analysis confirms. Therefore, we must not start from the assumption of the obligatory usefulness of each investment project implemented by foreign investors, but, in each individual case, the effects that really manifested on the economy of the country importing capital should be reviewed and subsequently determined.

Potential negative effects of foreign direct investment, especially characteristic of underdeveloped and developing countries are:

- Exploitation of natural resources;

- Causing environmental problems;

- Negative balance of payment effects;

- Endangering companies engaged in the same or similar activities;

- Endangering the partners of the acquired companies;

- Interference in domestic political turmoil;

- Impact on the economic policy of the host country;

- Influence on current laws with emphasis on the Labor Law;

- Formation of a consumption model that is not adjusted to the living standard of the host country, etc.

\section{Sources of rights for foreign direct investment in the territory of the Republic of Serbia}

The creators of economic policy in Serbia emphasize the positive aspects of foreign direct investments and in accordance with that, they attach great importance to them in the field of development of our economy, which is confirmed by the fact that since 2006 the policy of subsidizing foreign direct investments has been pursued. Namely, in 2006, the Government of the Republic of Serbia adopted the Strategy for Encouragement and Development of Foreign Investments and passed the Decree on the Conditions and Manner of Attracting Foreign Direct Investments. In the period from 2006 until today, the policy of subsidizing foreign direct investments has been maintained. The regulation controlling issues related to incentive funds intended for foreign direct investors has been amended several times during this period. The right to subsidies has been available to domestic investors since 2015 after the entry into force of the Investment Law, which replaced the 2002 Law on Foreign Investments. The Law on Amendments to the Law on Investments was passed in 2018. The criteria for awarding subsidies to investors are today defined within the Decree on determining the criteria for awarding incentives for attracting direct investments, which was adopted on January 19, 2019. 
The decree defines that the amount of incentive funds allocated to investors depends on the level of development of the local self-government unit in which they invest. All local self-government units are divided into five groups, so that the least developed local self-government unit is a devastated area. Investors are required to have a minimum investment value and a minimum number of workers who must be employed in order to be eligible for incentives. Finally, the amount of incentive funds is determined on the basis of eligible costs of gross wages for new jobs or on the basis of eligible costs of investment in fixed assets. Also, a combination of these two methods can be used provided that the amount calculated does not exceed the most favorable amount by resulting from the application of one or the other method of calculation.

Eligible costs are:

1. Investments in tangible and intangible assets starting from the day of submission of the application for allocation of incentive funds until the day of expiration of the deadline for realization of the investment project in accordance with the contract on allocation of incentive funds;

2. Eligible costs of gross salaries, which are gross salaries for new employees in the two-year period after reaching full employment with the beneficiaries of incentive funds;

3. Costs of renting business premises in which the investment project is being implemented in the period of implementation;

4. Costs related to the acquisition of leased property other than land and buildings are taken into account only if the lease takes the form of a financial lease and contains an obligation to purchase the property at the end of the lease period. (Official Gazette of the Republic of Serbia, 2019)

The criteria for allocating incentive funds and the manner of determining their amount are as follows:

1. For devastated areas, an investment of at least EUR 100,000 and employment of at least 10 new employees is required, in connection with which incentive funds in the amount of $40 \%$ of eligible costs of gross salaries may be awarded, in the maximum amount of EUR 7,000 per newly created job or up to $30 \%$ of the amount of eligible costs of investment in fixed assets;

2. For local self-government units classified in the fourth group according to the level of development, an investment of at least EUR 200,000 and employment of at least 20 new employees is required, in connection with which incentive funds in the amount of $35 \%$ of eligible costs of gross salaries may be awarded and in the maximum amount of 6,000 euros per newly created job or up to $25 \%$ of the amount of eligible costs of investment in fixed assets;

3. For local self-government units classified in the third group according to the level of development, an investment of at least 300,000 euros and employment of at least 30 new employees is required, in connection with which incentive 
funds in the amount of $30 \%$ of eligible costs of gross salaries may be awarded and in the maximum amount of 5,000 euros per newly created job or up to $20 \%$ of the amount of eligible costs of investment in fixed assets;

4. For local self-government units classified in the second group according to the level of development, an investment of at least 400,000 euros and employment of at least 40 new employees is required, in connection with which incentive funds in the amount of $25 \%$ of eligible costs of gross salaries may be awarded and in the maximum amount of 4,000 euros per newly created job or up to $15 \%$ of the amount of eligible costs of investment in fixed assets;

5. For local self-government units classified in the first group according to the level of development, an investment of at least 500,000 euros and employment of at least 50 new employees is required, in connection with which incentive funds can be allocated in the amount of $20 \%$ of eligible costs of gross salaries may be awarded and in the maximum amount of 3,000 euros per newly created job or up to $10 \%$ of the amount of eligible costs of investment in fixed assets.

\section{Assessment of the treatment of foreign direct investments in the domestic legislation and economic policy of the Republic of Serbia}

There is a question whether the subsidy policy is necessary, whether it is justified, and if it is in force, whether the criteria for allocating incentive funds are set to contribute to the manifestation of positive effects of foreign direct investments whose inflow has been realized.

The first criterion, the level of development of local self-government, is most likely determined by the example of the practice of granting state aid to underdeveloped regional areas which is applied in the European Union. (Gnjatović, 2016, p. 131) The criterion that determines which are desirable investments for a certain region has not been set, and it would be of great importance because it would contribute to creating the desired production structure of the economy that would play the role of our entrance into modern international economic flows. The answers to the following questions are important for creating such a criterion: What are the comparative advantages of our economy? Which fields should be developed in accordance with the trends on the world market? In which fields should domestic investments be encouraged, and in which fields is foreign investment assistance desirable in order to develop it? What are the competitive advantages of our economy, and what could we potentially develop? All this leads us to the conclusion that setting criteria for granting incentives is a complex task, if we want them to contribute to the positive effects of foreign direct investment, and that they must be adapted to the characteristics of our economy in cases where their creation is based on the practice of some developed countries.

A shift in the direction of creating such criteria can be seen in the Law on Amendments to the Law on Investments, which as an investment of special 
importance, an investment that realizes the right to state aid, defines what contributes to improving the competitiveness of the industry. However, as already stated, the contribution of the competitiveness of the industry is not obligatory in the case of every investment, so the answer to the question whether the investment project will show such an effect would require a special analysis or at least defined basic requirements related to this issue in laws and bylaws. However, despite the great complexity, no greater attention was paid to that issue. This means that it has not been elaborated in detail either in the Law or within the Regulation, so it is upon us to conclude that it is left to local authorities and other competent authorities to determine whether the investment contributes to the competitiveness of the industry or not.

The focus of the demands placed on investors is the number of new employees and the total value of the investment. According to the author Kovačević (2016), it is debatable whether the value of an investment can be used as a criterion for its quality, and even more problematic is the inconsistent calculation of the value of investment projects as a result of the fact that neither the law nor bylaws vary from case to case. It is also questionable how adequate it is to use the combination of the number of employees and the total value of the investment, as a criterion on the basis of which the amount of incentive funds is determined, because projects that employ more have fewer capital requirements per employee and vice versa.

The requirements set before foreign direct investors as done under the current regulation do not stimulate the inflow of projects based on high-tech products. Then, they do not encourage cooperation of foreign direct investors with domestic companies, and it is omitted to stimulate the inflow of those investments whose needs in their realization would be harmonized with the capacities of the domestic economy that could supply them with domestic raw materials and semi-finished products. Therefore, the steps that would ensure the spillover effect were omitted. In addition, although the formal subsidy procedure is defined by a regulation, individual negotiations are conducted by each individual investor, resulting in a specifically designed way of subsidizing. State aid procedures are non-transparent, which can be problematic in several aspects.

Investors choose a location to invest in accordance with its expected profitability. The profitability of investing depends on the advantages of the investment location and the motive for investing. The advantages that Serbia provides are reflected in the following: strategic positioning in the markets of Europe, Asia and the Middle East and logistical advantages that the location provides, a large percentage of English-speaking residents, available natural resources, signed free trade agreements that reduce export costs, market access of about 7 million consumers, low operating costs caused by low costs of electricity, gas and other fuels compared to other European countries, low income tax rate compared to other European countries. (Aranđelović, 2008, p. 105) 
Are subsidies necessary for investors to place their capital on our market despite the stated advantages? What are the main shortcomings of Serbia as an investment location that deters investors from investing, but which the state is trying to compensate with subsidies?

The main shortcomings of Serbia as an investment location can be identified: regulatory and bureaucratic obstacles, legal uncertainty, high corruption, high costs of bankruptcy proceedings, insufficiently developed infrastructure, difficult access to bank loans, the insufficient representation of non-bank financing, the need to reorganize and improve the tax administration.

Subsidies cannot eliminate these shortcomings, although they are promoted in public as a means of improving the attractiveness of the investment environment. Available information on the surveys of investors operating in Serbia shows that government incentives are not at the top of the list of the factors considered in assessing the investment environment and that investors will be primarily interested in economic and institutional factors. When making a decision on the choice of investment location, the foreign investor will primarily consider economic and political stability, legal security, infrastructure development, access to financial resources, and the business climate.

Also, the motive of investors is always the realization of the investment option, which they assess as profitable. The motive for investing in a certain location cannot be subsidies because they are temporary. If the investment is not profitable without subsidies, it should not be invested in. If such an investment were to be made, it is clear that it would be limited in time, temporarily, and there was no guarantee that such engagements could be beneficial to the economy. (Madžar, 2016, str. 33)

\section{What are the results of subsidy policy?}

According to the World Bank report, in the period from 2013 to 2017, total investments in Serbia averaged $18.8 \%$ of GDP, and in 2018 it grew to $22.7 \%$ of GDP. In 2019, the share of total investments in GDP was $24.6 \%$, according to the data of the National Bank of Serbia.

The chart made by the World Bank analysts shows that the share of total investments in GDP in Serbia is lower than the average of the Western Balkan countries and the countries of Central and Eastern Europe. On the other hand, Serbia has had a relatively high share of net foreign direct investment in total investment in recent years, which is even higher than the average of Central and Eastern European countries, as well as the countries of the Western Balkans. However, it should not be forgotten that the countries of Central and Eastern Europe appear not only as significant recipients of foreign capital, but also as significant investors abroad, which affects the share of their net foreign direct investment in GDP. (Arsić, Randjelović, \& Nojković, 2019, p. 49) 


\section{Picture 1. Investments of Serbia in comparison with neighboring countries and countries of Central and Eastern Europe, in the period from 2001-2018}

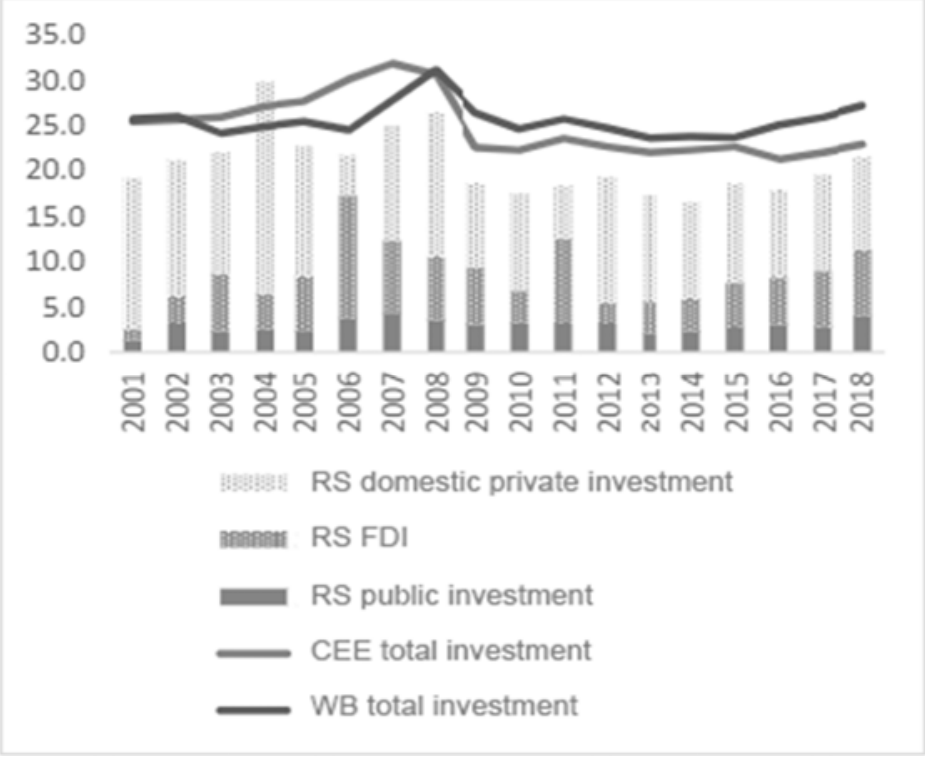

Source: New agenda for economic growth in Serbia developed by World Bank analysts in 2019

The share of domestic private investment in Serbia is lower by 3\% of GDP compared to other Western Balkan countries and by 6\% of GDP compared to Eastern and Central European countries. Public investment was lower by more than $2 \%$ than in the Western Balkans and by 1.3\% lower than in Eastern and Central Europe. Domestic private investments in Serbia have been declining in recent years. The share of domestic private investment in Serbia in total investment is significantly below the average of other countries in transition.

In the period from 2007 to 2019, the average share of foreign direct investment in GDP was $6.51 \%$. In 2019, it amounted to $8.33 \%$, which is above the average of the observed countries.

When it comes to the structure of attracted investments, i.e. in terms of their qualitative characteristics, in the period from 2006 to $2019,49.2 \%$ of the total value of subsidies granted to investors was awarded to projects of low and medium low technological complexity, while only $2.1 \%$ of subsidies supported projects in the field of high technology. The total investments are dominated by projects of medium high technological complexity, which are mostly in the field related to the production of parts for the automotive industry, most often the production of various cable assemblies, low added value, with the engagement of low-skilled labor. In the same period, $93.5 \%$ of incentive funds were allocated to foreign investors, and $6.5 \%$ to domestic investors. (Filipović \& Nikolić, 2020, pp. 87-94) 
Picture 2. Domestic private investments in the transition countries of the Western Balkans, Eastern and Central Europe

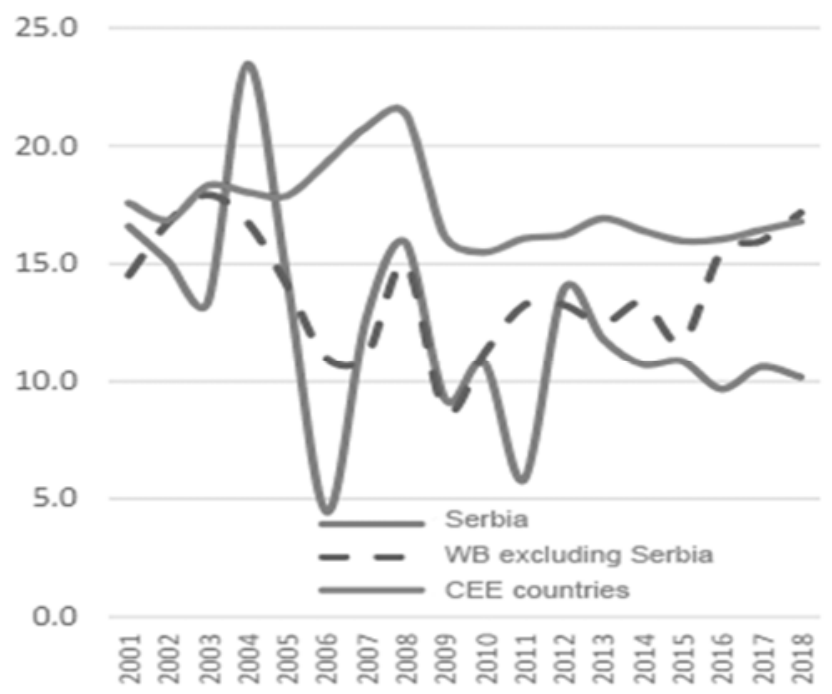

Source: New agenda for economic growth in Serbia developed by World Bank analysts in 2019

In recent years, there has been a relatively high inflow of greenfield investment that has provided new jobs, but most of these jobs have focused on the process of direct physical production, intended for manual workers who perform routine operations and have the status of cheap low-skilled labor. This is a result of the fact that the largest share in greenfield investments have projects aimed at the production of cable assemblies. World Bank analysts pointed out that although a satisfactory inflow of foreign direct investment was achieved, most of the jobs created in this way were in less productive companies and those engaged in the production of lower value-added products, so productivity grows slowly, only for $1 \%$ per year. (New agenda for economic growth of Serbia, 2019)

Another problem that arises in this field is the large number of recorded examples of non-compliance with the Labor Law by foreign investors. It can be said that foreign investors have found a way to use the legal uncertainty and high corruption that characterize Serbia as a tool for achieving higher profits, and that is certainly not in the interest of the domestic economy. Health as a component of human capital, impaired through this practice, is of immense importance for the economic development of the country. When it comes to workers' wages, it is in the interest of the host country to make them as high as possible.

The half of Serbia's exports come from foreign-owned companies. So, a large number of foreign companies are export-oriented, but at the same time dependent 
on imports. In other words, these companies obtain a small part of their raw materials in the country. The share of domestic inputs with the exception of labor and energy is about $9 \%$ of total inputs, which means that $90 \%$ is imported. FIAT can be cited as a good example of this. On the other hand, products such as components of vehicles, electronic equipment, tires, metal semi-finished products, plastics are exported. In other words, the complexity of the total basket that Serbia exports is declining. (New agenda for economic growth of Serbia, 2019)

Subsidies mostly went to activities of low technological complexity. The largest percentage of attracted foreign direct investments is motivated by cheap labor. There is an influx of investment projects that do not apply innovative and high-tech procedures, nor bring research and development functions. In addition to the fact that there are no high-tech functions about which knowledge would be transferred to domestic companies, there is no cooperation with them. As the World Bank analysts conclude, in such circumstances, there is no possibility to achieve the effect of spillovers and the inclusion of local companies in global economic flows. At the same time, there has been a decline in the productivity of foreign companies in recent years. World Bank analysts recommend that government agencies implement more programs to support small and mediumsized enterprises and encourage domestic private investment. (New agenda for economic growth of Serbia, 2019)

The effect on the budget is questionable due to the allocation of generous subsidies and large tax reliefs and tax exemptions, but it could easily be assessed through a comparison of revenues and expenditures that the country had at the level of individual investment projects. Such analyses are not available to the public, while academic circles cannot perform them due to unavailable data.

\section{Conclusion}

Foreign direct investment is the basic means of growth of multinational companies and the basic mechanism of globalization. At the level of developing countries, they are promoted as the best instrument that can compensate for the lack of domestic accumulation and play the role of a driver of economic growth and development.

The fact that quantity does not necessarily provide the required quality is confirmed by Serbia's experience in attracting foreign direct investments. Although it has achieved a significant inflow of this type of investment capital in recent years, its impact on overall economic trends cannot be assessed as satisfactory. The insufficient efficiency of the policy of attracting foreign direct investments is reflected primarily in the technological structure of investments whose inflow has been realized, the lack of transfer of modern technology, knowledge, equipment, innovative processes, new organizational and management techniques. Foreign 
direct investors are on the list of our largest exporters, but also importers. Serbia is constantly recording a current account deficit. The complexity of the basket of export products is reduced in favor of raw materials, semi-finished products, lowstage processing products and low value without major comparative and competitive advantages in the global market. Promoting cheap low-skilled labor, as a basic advantage of Serbia as an investment location, becomes a major concern. Serbia has joined the race to attract investors with cheap labor whose employment is subsidized. As this trend of promoting the workforce continues, it has a disincentive effect on the highly educated workforce, the number of which is constantly decreasing due to the worrying brain drain. In a relatively long period of investor subsidies, from 2006 until today, the expected development of domestic companies through cooperation with foreign investors has not occurred, which would have a stimulating effect on increasing domestic accumulation, while domestic private investments are declining and low. According to all the above mentioned, we conclude that the subsidy policy was unsuccessful and should, therefore, be abandoned.

Foreign direct investments, as presented in the first part of the paper, can be very desirable for the economy, but they must contain high-tech functions and be integrated into the domestic economy, i.e. achieve cooperation with local companies. As it is clarified, there is no need for subsidies if there is a profitable project and friendly investment environment. These are multinational companies that have great economic power and, therefore, do not need state assistance to cover operating costs. Therefore, the subsidy policy is not justified.

We should focus on creating a more favorable investment environment, providing an adequate level of assistance to entrepreneurs, small and medium enterprises, while respecting the country's comparative advantages and trends in the world market with the aim of creating a competitive domestic economy. Funds allocated in the form of subsidies to foreign direct investors, which have mostly gone to the activities of low technological complexity, can be redirected to research and development, higher education, encouragement of innovative entrepreneurship.

According to Paul Romero, a well-known American economist, physical capital is a scarce growth factor and as such is subjected to the law of diminishing returns, so it cannot be a guarantee of long-term economic growth. Ideas and knowledge as components of human capital are not subjected to the law of diminishing returns. If the state wants to support economic growth, it must support the increase of human capital, which is a key generator of economic growth. People possess unlimited abilities to reconfigure physical capital, thus creating new patterns of their use that contribute to productivity and accelerate economic growth. (Cvetanović \& Mladenović, 2015)

It is clear from the above why the characteristic of modern economies is the constant increase in the share of human capital in the structure of total capital, while 
due to low investments of our state in research and development, weak links between science and economy and the unsuccessful strategy of introducing workers to new technologies and management techniques, through the inflow of foreign direct investment to Serbia, it cannot be said that Serbia is going in the same direction.

Reforming the legal system, reducing the level of corruption, eliminating inefficient administrative procedures would be an important first step towards creating a more attractive investment location. Domestic private investments, higher education, science, research and development must be Serbia's priority. Using Schumpeter's view that expected earnings drive individuals to research and innovate, it can be concluded that they only need a competitive and equitable environment in which they will be able to reap the fruits of their labor.

\section{UTICAJ TRETMANA STRANIH DIREKTNIH INVESTICIJA U DOMAĆEM ZAKONODAVSTVU NA PRIVREDNI RAZVOJ REPUBLIKE SRBIJE}

Rezime: U Srbiji se od 2006. godine vodi politika subvencionisanja stranih direktnih investicija i pridaje veliki značaj ovom vidu investicionog kapitala na polju razvoja naše privrede. Da li se ovo može oceniti kao opravdano je pitanje na koje ovaj rad ima za cilj da pruži odgovor. Da li pozitivni aspekti stranih direktnih investicija obavezno dolaze do izražaja u zemlji uvoznici kapitala? Analiza pozitivnih efekata stranih direktnih investicija na privredu zemlje domaćina pokazuje da višestruke koristi ovako privučenog kapitala svakako postoje, ali da njihovo ispoljavanje nije bezuslovno i da će zavisiti od mnogobrojnih faktora. S obzirom na to da je politika subvencionisanja aktuelna, kriterijumi za dodelu državnih podsticaja definisani važećom uredbom bi trebalo da budu postavljeni tako da doprinose ispoljavanju pozitivnih efekata stranih direktnih investicija na privredu Srbije. Međutim, njihova analiza pokazuje da ovo ipak nije slučaj. Pored toga, uticaj koji su strane direktne investicije imale na privredu Srbije ukazuje na to da politika subvencionisanja nije dala očekivane rezultate. Imajući ovo u vidu, uticaj koji tretman stranih direktnih investicija u domaćem zakonodavstvu ima na privredni razvoj Republike Srbije ne može se oceniti kao zadovoljavajući.

Ključne reči: strane direktne investicije, subvencije, Srbija, privredni razvoj, strani investitori, zakonska regulative. 


\section{Authors' biographies}

Milica Vukajlović was born in 1997 in Kruševac. She graduated from High School in Brus, educational profile Economic Technician. In 2016, she enrolled at the Faculty of Economics, University of Nis, study programme Accounting, Auditing and Financial Management. She is a scholarship holder founded by the Fund for Young Talents - Dositej. She graduated in 2020 and after that she enrolled in master studies at the Faculty of Economics, University of Nis, programme Economy, module International Management.

Dragana Radenković Jocić works as a Full professor in a field of Business Law (Commercial Law, EU Law, Corporate Governance, EU Competition Law). She is the vice-dean for the scientific work, in period 2006-2009, as well as 2018-currently. She was managing or participating in numerous projects: She is author of four textbooks in a field of Commercial Law and Corporate Governance, in a period 2002-2019, four monographs, and more than 150 articles: a part of all published article.

Tamara Milenković Kerković is a Full Professor at the Faculty of Economics, University of Niš and she teaches Commercial Law and International Trade Law at the undergraduate level of study and Banking Law and Competition Law at Masters and doctoral level of study as well. Her fields of specialization include commercial conctracts, franchising law, payement protection law and consumer protection law. 